\title{
Chemical exchange captures Nobel
}

崩

This year's Nobel Prize in Chemistry has been won by three researchers who pioneered the understanding and use of a very general class of reactions that aid the construction of carbonbased (organic) molecules.

Yves Chauvin of the French Petroleum Institute in Rueil-Malmaison showed how these 'metathesis' reactions, long familiar to the petrochemicals industry, actually work.

This understanding helped Richard Schrock at the Massachusetts Institute of Technology (MIT) in Cambridge and Robert Grubbs of the California Institute of Technology, Pasadena, to develop catalysts that made metathesis more controllable and reliable.

Thanks to the trio's work, metathesis is now widely used in the synthesis of many organic compounds, from plastics and pharmaceuticals to herbicides. ${ }^{\alpha}$ It has fundamentally transformed the way chemists think about building new molecules," says Gregory Fu at MIT, who was a postdoc with Grubbs.

The award "is what we've all been waiting for ${ }^{n}$, says Steven Ley, an organic chemist at the University of Cambridge, UK. ${ }^{\alpha}$ The work is spectacularly useful and important - it is the chemistry discovery of the past 30 years."

Metathesis has taken a route - not unusual in chemistry - from industry to the academic laboratory and then back out to industry. In the process, it has been transformed from a curious observation to a useful piece of science.

${ }^{\star}$ People knew there was this funny reaction

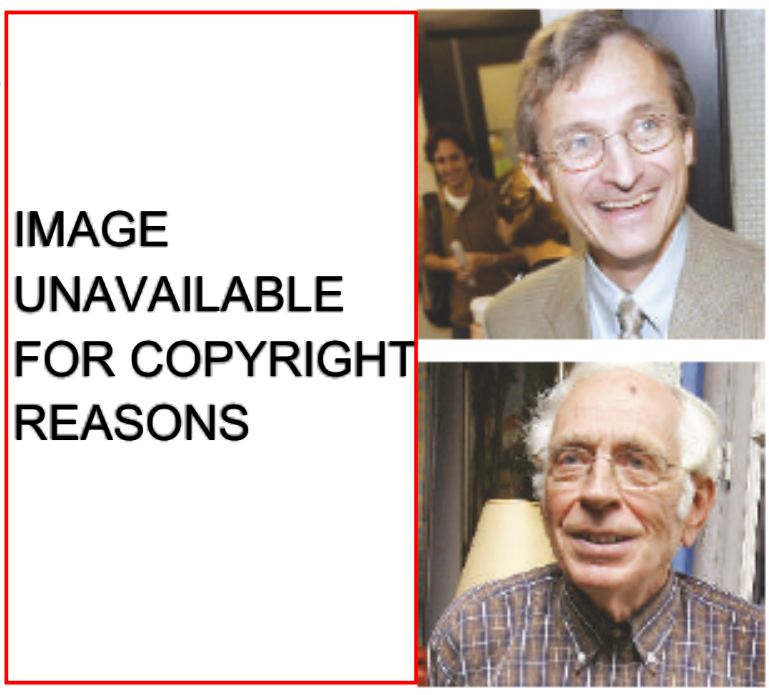

Robert Grubbs (left), Richard Schrock (top) and Yves Chauvin transformed metathesis from a curiosity to a key chemical tool.

in petroleum refining," says John Brown, an organic chemist at the University of Oxford, UK. ${ }^{\alpha}$ Chauvin came up with the first serious mechanism that turned it into rational design. But it was still just a party piece until Schrock came along."

Metathesis involves two molecules that each contain a double bond between carbon atoms - the bond acts rather like a double handclasp between a pair of dancers. During the reaction, which requires a catalyst containing metal atoms, the molecules effectively exchange partners (metathesis means 'changing places'). "The molecules are cut in half and put back together again," says Brown.

In 1971, Chauvin showed how the metal-atom catalyst coordinates this rearrangement. Soon after, Schrock began to look for more effective catalysts and, by 1990 , had found that compounds containing molybdenum and tungsten were especially efficient.

But Schrock's catalysts still $\frac{\text { a }}{2}$ tended to react with other molecular groups attached to the double bonds. In 1992, Grubbs discovered that ruthenium compounds interfered less with other groups, and were more stable in air. ${ }^{\text {"That really }}$ rocketed the reaction into common usage," says Ley.

"The availability of these improved catalysts has revolutionized organic synthesis," he adds. "I don't think there is a single organic chemist who hasn't used metathesis."

The award is a reminder that, in chemistry, the best contributions are often not discoveries, but tools. A general way of making new molecules can find many different applications. ${ }^{\alpha}$ Most people have these catalysts on their shelves," says Fu.

Philip Ball

\section{Ig Nobels hail world's longest-running experiment}

\section{BOSTON}

Unlike other days at Harvard University, the first Thursday in October is a time when levity overtakes gravity, irreverence prevails over reason, and the flight of paper aeroplanes is actively encouraged. It is time, in other words, for the Ig Nobel Prize Ceremony.

At the fifteenth Ig Nobel ceremony, held on 6 October before a boisterous crowd in Harvard's Sanders Theatre, ten prizes were awarded to winners from a dozen countries. Winners travelled from as far as Australia and Japan to take home the 'Ig', a prize devoted to "achievements that first make people laugh, and then make them think".

The biology prize, for example, went to an international team for smelling and cataloguing the odorous secretions of 131 species of stressed-out frog. In work that earned them the chemistry prize, two researchers from the University of Minnesota in Minneapolis showed that people can swim as fast in syrup as in water (see Nature doi:10.1038/news040920-2;2004).

John Mainstone of the University of Queensland in Australia accepted the physics prize for the 'pitch-drop' experiment started back in 1927 by the prize's co-winner, the late Thomas Parnell. It shows that an ostensibly solid tar derivative can behave like a liquid, forming drops at the rate of about one every nine years.

Shortly after arriving at Queensland in 1961, Mainstone found a curious piece of equipment tucked away in a cupboard. He had unwittingly stumbled across Parnell's experiment, by then three decades old.

Parnell, Queensland's first physics professor, had taken a sample of pitch, heated it, and placed it in a funnel. He hoped to show that this apparently solid substance - brittle enough to shatter on impact - has fluid-like properties. Sure enough, the material did form drops, albeit at an exceedingly slow rate. Its viscosity, Mainstone and his colleagues calculate, is 100 billion times that of water.

It is hard to know what motivated Parnell, but Mainstone suspects it had to do with the quantum revolution - the idea that "things are not what they seem" - that had overtaken physics. "This was his way of showing there are strange things in classical physics too, ${ }^{n}$ Mainstone surmises. 
The experiment has attracted a cult following, he says, yet it also raises some serious scientific questions. No one knows, for example, how each drop actually detaches. Mainstone believes that fibres supporting the drop in its final stages become unstable and fail catastrophically, but this hypothesis is unconfirmed.

Part of the problem is that in the experiment's 78-year history, no one has seen a single drop fall. That's not surprising, says Mainstone. "We're talking about a descent of a few centimetres, lasting a tenth of a second, that occurs just once a decade." The last drop, which fell in November 2000, should have been recorded on a webcam, but technical problems intervened. "We'll have to wait until next time, which could be 2010 or later," Mainstone notes.

There is enough pitch left to sustain the experiment for another century, he estimates, and he hopes it will continue, despite the constant battles he has waged with the "philistines" who believe the experiment wastes precious time and space. Mainstone's labour of love, along with Parnell's pioneering work, were recognized in 2003 when the Guinness World Records named the pitch-drop demonstration the world's longest-running laboratory experiment. The Ig Nobel prize, which Mainstone shares with the late

\section{IMAGE \\ UNAVAILABLE FOR COPYRIGHT REASONS}

John Mainstone steps up to accept his award for an experiment begun almost 80 years ago.
Parnell, provides further recognition.

Looking to the future, Mainstone has already picked a successor, his former student Andrew White, to oversee the project when he finally steps down.

Mainstone never imagined that he would look after this experiment for four-and-ahalf decades, but says he has become "enthralled by the historical continuity of it all". A shiny drop of pitch, which gradually changes in shape from a sphere to a pear, is "a thing of beauty", he says. While acknowledging the importance of quantum mechanics, he can't help but wonder: "Is the pitch drop any less fascinating than wave-particle duality?"

Mainstone is a great believer in the Ig Nobels, and not just because of his award. Science has become a "rat race", largely as a result of the pressure to competefor grant money, he claims, adding that it's important to get a break from that sometimes. "When we cease to see the amusing side of science, it's all over," he says.

Steve Nadis 